\title{
ARTIFICIAL RECHARGE THROUGH TREATED WASTE WATER
}

Anita Dubey,

Govt. M.L.B. Girls P.G. Autonomous College Bhopal.

ORCID:

Email: anitadubey04@gmail.com

\section{Electronic version}

URL: http://www.researchinspiration.com

DOI: https://doi.org/10.53724/inspiration/v6n2.07

ISSN: 2455-443X

Vol. 6, Issue-II, March 2021

Page No. 38- 42

Publisher

Welfare Universe

Electronic reference/Article is to be Cited:

Anita Dubey, (2021). Artificial Recharge Through Treated Waste Water. Research Inspiration: An

International Multidisciplinary e-Journal, ISSN 2456-443X, 6(II), 38-42.

https://doi.org/10.53724/inspiration/v6n2.07

OResearch Inspiration: An International Multidisciplinary e-Journal 2021. This Open Access article is published under a Creative Commons Attribution Non-Commercial 4.0 International License https://creativecommons.org/licenses/by-nc/4.0/, which permits non-commercial reuse, distribution, and reproduction in any medium, provided the original work is properly cited. For citation use the DOI. For commercial re-use, please contact editor email:- publish1257@ gmail.com By accessing the work you hereby accept the Terms. Non-commercial uses of the work are permitted without any further permission from Research Inspiration: An International Multidisciplinary eJournal provided the work is properly attributed.

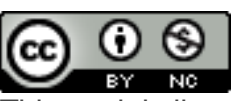

This work is licensed under a Creative Commons Attribution-NonCommercial 4.0 International License. 


\title{
ARTIFICIAL RECHARGE THROUGH TREATED WASTE WATER
}

Anita Dubey,

Govt. M.L.B. Girls P.G. Autonomous College Bhopal.

ORCID:

Email: anitadubey04@gmail.com

\begin{abstract}
Artificial recharge is a process where water is introduced into the subsurface and is directly linked to the amount of water that enters an aquifer through human controlled means. Water that has been negatively affected in quality by human is termed as wastewater and it must be treated before it is used for artificial recharge of the ground water. The growth rate of various development sectors of the country is dependent on the availability of water resources therefore conservation, reclamation and reuse of water are receiving great importance.
\end{abstract}

Keywords: Artificial recharge, wastewater, treated, water resources.

\section{Introduction}

Artificial recharge with treated wastewater is a natural extension of conservation of groundwater resources and the treatment of wastewater across the globe is crucial to reduce pollution and achieve water quality improvements. In the present day ground water depletion is a critical issue throughout the world. Artificial recharge of ground water using waste water continues to increase worldwide in cities or towns having a large population and limited water supply to control water depletion in overexploited aquifers. ${ }^{1}$ Supply of safe water in adequate quantity to all communities is the basic need and monitoring of water quality is essential for assessing the overall health of water bodies. The part of rain water which percolates through the earth surface known as ground water is an important source of drinking water and water used in agricultural and industrial sector. Artificial recharge is a process where water is introduced into the subsurface and is directly linked to the amount of water that enters an aquifer through human controlled means. Recharge occurs both naturally (through the water cycle) and artificially (through anthropogenic means) where rain water and reclaimed water is routed to the subsurface. ${ }^{2}$

\section{Purpose of artificial recharge}

Water one of the basic needs of life is essential for survival. With the rapid population growth and industrialization, conservation reclamation and reuse of water are receiving great importance. The basic purposes of artificial recharge are:

Raising declining water table,

Storage of water,

Boost the natural supply of ground water aquifers,

Flood control,

Water reclamation and management, 


\section{Why artificial recharge through sewage}

Sewage includes domestic, municipal or industrial liquid waste products. Sewage contains harmful substances which endanger the health of aquatic environment as well as human health when we dump sewage into our water aquifers. At present technologies are used around the world to recover valuable resources from sewage to generate energy, nutrients and water for irrigation and industrial purposes. Today about $80 \%$ of all wastewater is discharged into water bodies where it creates environmental and health hazards, therefore sewage treatment plays important roles in sanitation and disease prevention.

\section{Importance of sewage treatment}

Sewage is host to microbes and pathogens which contaminate the local environment and water bodies; therefore treatment of sewage is very important to restore the water supply with recurring droughts in many areas of the world and to protect the environment from toxin. Thus the use of waste water recycling systems offers a process of saving water and reducing sewage volumes.

\section{Characteristics and composition of sewage}

- Sewage is highly turbid having high BOD due to presence of large amount of organic matter which on anaerobic decomposition generates hydrogen sulphide $(\mathrm{H} 2 \mathrm{~S})$.

- Sewage is slightly alkaline contains intestinal bacteria, aerobic and anaerobic bacteria.

- In addition sewage effluent contains metals, enzymes, algae, fungi, virus, protozoa, phenols and other organic compounds.

- Temperature of sewage is slightly higher than that of ground water due to evaluation of heat when its organic matter is decomposed.

- Sewage is grey to dark in color, having characteristic odor.

\section{Stages of sewage treatment}

The best way to utilize the sewage water is to treat it and then artificially recharge the water. Once sewage reaches treatment plants, four stages are involved including:

Pre-treatment: to remove grit and gravel and screening of large solids.

Primary treatment: During the treatment wastewater is temporarily held in a settling tank to settle larger suspended matter works on sedimentation. The remaining liquid is moved for secondary treatment.

Secondary treatment: It works on deeper level using aeration, bio-filtration and interaction of waste to degrade the biological contents of the waste and reduce residual organic matter.

Tertiary treatment: It is aimed to address different pollutants using different treatment processes and to raise the water quality to domestic and industrial standards.

Once the sewage has been treated the water can be used for artificial recharge purposes and for irrigation, industrial and domestic use.

\section{Artificial recharge through treated waste water}

The water after treatment can be put into the wells which can be dug with about 2-4 meter diameter and depth in the area of previous underground strata. At the base brickbats be placed at the base and then treated water can be put into the well. The water will be recharged to the ground which can be used for agricultural as well as domestic purposes. The material removed during the treatment of sewage can be used as manure. ${ }^{3}$ Artificial recharge of ground water by treated waste water is one of the most effective methods for augmentation of ground water resources. ${ }^{4}$ From the economic and practical point of view 
the most effective recharging techniques deep injection wells, shallow wells and the surface spreading basins have been applied. Some researchers are rejecting the deep injection wells as the models showed that it can pollute the deep aquifers.

\section{Methods of ground water recharge}

Factors that affect the artificial recharge of ground water through treated waste water are availability, quality and quantity of waste water, underground storage space available, its depth, applicable methods, costs, cultural and social considerations and legal constraints etc. Direct recharge methods are spreading method, recharge pits, shafts, ditches and wells and indirect recharge methods are induced infiltration and conjunctive well. ${ }^{5}$

\section{Conclusion}

The best way of recharging water aquifers is to utilize the treated waste water which can significantly increase the sustainable yield of the aquifer. Periodic maintenance of ground water recharge structures is essential to boost the natural supply of ground water aquifers. Artificial recharge techniques are easy and cost effective which can manage sustainably to rise ground water level or to reduce the rate of the decline. Sewage is often treated by various onsite sanitation systems and not conveyed in sewers in rural areas with low population densities.

\section{References}

1. Kostas Vouduris, Artificial recharge via Boreholes using treated waste water: possibilities and prospects, water 2011,3(4),964-975, https://doi.org/10.3390/w3040964

2. Ground water recharges en.wikipedia.org

3. Ground water recharge by Gautam Mahajan pp119-135

4. Artificial recharge of ground water by treated waste water, (August2018)

https://www.researchgate.net/publication/327059909 Artificial Rechrge of Groundwater by Treated Wastewater

5. Prof. Asif P Shaikh, Prf Avinash V Navale, Prof Bala Saheb, E Gite, Prof Madhuri K Rathi, Ground water recharge by waste water https://www.engineeringcivil.com/groundwater-recharge-by-waste-water.html

6. Artificial Recharge of Groundwater: https://www.engineeringcivil.com/artificial-recharge-of-groundwater.html

7. Sewage treatment: https://en.wikipedia.org/wiki/Sewage treatment

\section{Annexure-A,}

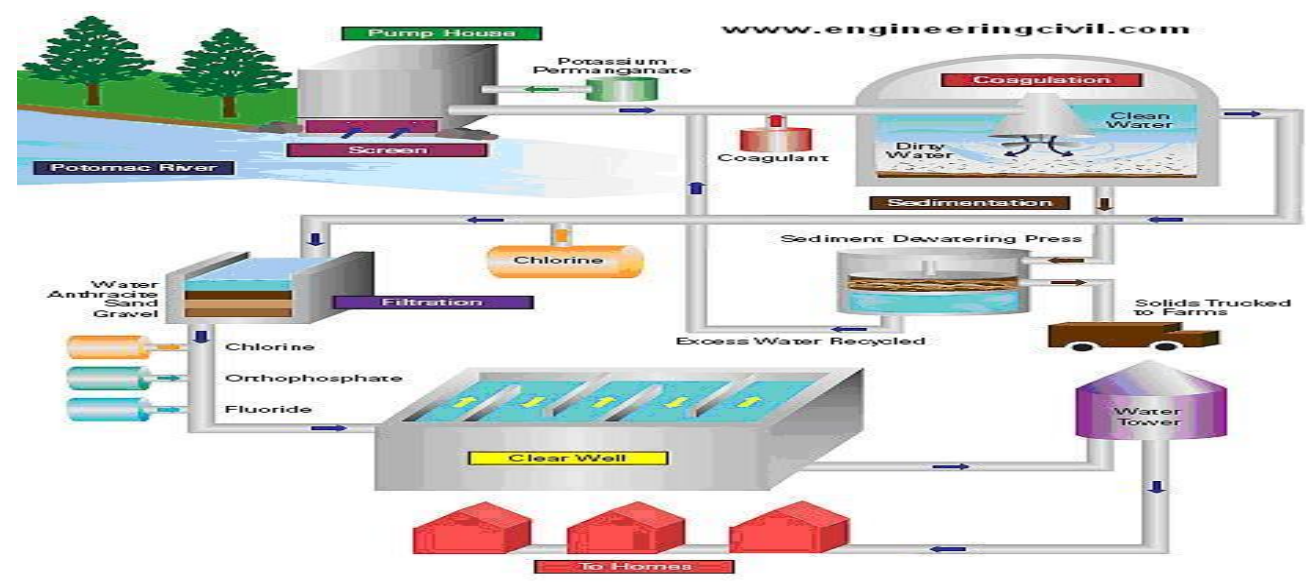

Waste water treatment system 
Annexure-B,

Methods of artificial recharge [6]
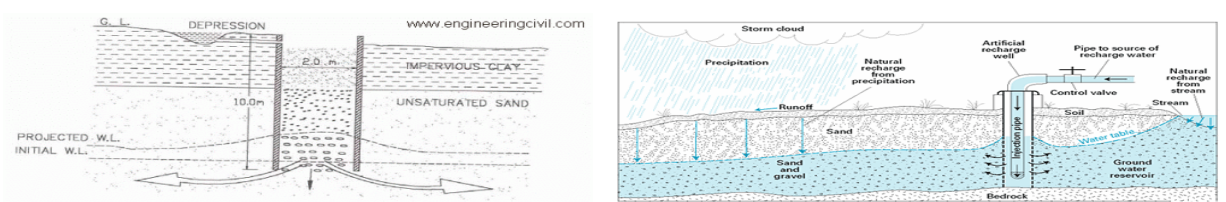

Vertical recharge shaft without injection well and with injection well

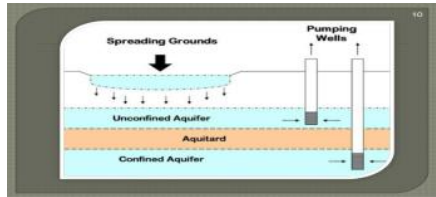

Spreading Method

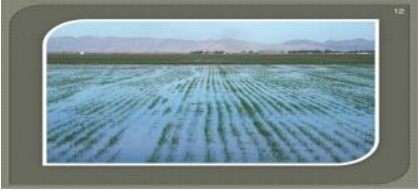

Flooding Method

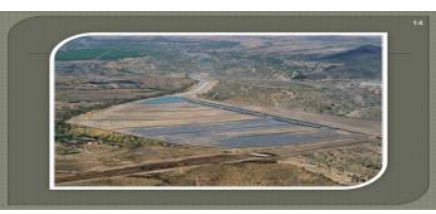

Basin Method

$* * * * * * * * * * * * * * * * * * * * * * * * * * * *$ 